\title{
Anaerobic digestion of piggery waste. 2. Start-up procedure
}

\author{
A. F. M. van Velsen
}

Agricultural University, Department of Water Purification, De Dreyen 12, Wageningen, the Netherlands

Accepted: 22 January 1979

Key words: anaerobic digestion, piggery waste, acclimation, ammonia-nitrogen

\section{Summary}

The influence of the loading rate on the starting of pig manure digesters seeded with digested sewage sludge was investigated in both laboratory and pilot plant experiments.

The digested sewage sludge appeared to be a suitable seed material. However, in all experiments a period of unbalanced digestion took place, which mainly can be attributed to an inhibition of the methane formation by ammonia-nitrogen at concentrations exceeding $1.7 \mathrm{~g} /$ litre. It was shown that the methanogenic organisms acclimate to these ammonia-nitrogen concentrations and once being acclimated can digest at much higher ammonia-nitrogen concentrations.

In all experiments, applying initial sludge loads in the range of 0.07 to $0.125 \mathrm{~kg}$ $\mathrm{COD}^{*} \mathrm{~kg}^{-1} \mathrm{VS}^{*}$ day ${ }^{-1}$, the digestion process was started successfully. Although the initial loading rate influenced the course of the digestion in the period of unbalance, it did not affect the final digestion characteristics after the recovery of the process.

\section{Introduction}

Anaerobic digestion of animal wastes has received increased attention, mainly because the process offers the combination of energy recovery and pollution control. Consequently at present the farm-scale application of anaerobic digestion for these purposes is increasingly taken into consideration. With respect to the expected farm-scale application of the process a proper start-up procedure, i.e. not requiring intensive supervision, should be available. This condition seems to be met for digesters treating ruminant wastes, because ruminant wastes as a rule contain sufficient anaerobic organisms, acid-forming as well as methane-forming, to start the digestion process without seeding. However, in the manure of nonruminants such as pigs and poultry the concentration of the very specific methanogenic organisms is relatively low. Together with the slow growth rate

* $\mathrm{COD}=$ chemical oxygen demand $\mathrm{VS}=$ volatile solids. 
of these organisms, this will result in an extended period of digester start-up, unless seed material is added (Hobson \& Shaw, 1973). Therefore seeding of digesters for the treatment of pig and poultry wastes is recommended.

Undoubtedly the most suitable seed material is the mixed liquor from a digester treating the same waste. However, since anaerobic digestion of farm wastes still is not extensively applied up to now, other seed materials should be considered. Obviously for this purpose digested sewage sludge from municipal sewage plants is attractive (1) because as a rule this material is the only enriched methanogenic inoculum generally available in large quantities and (2) because it may be expected to be a suitable seed material for the digestion of substrates being as complex as raw sewage sludge, viz pig manure.

This article deals with the results of some laboratory and pilot plant experiments concerning the acclimation of digested sewage sludge to wet piggery waste. The main objective of the investigation was to establish some practical directions for starting anaerobic digesters for pig manure and similar substrates.

\section{Material and methods}

\section{Apparatus}

Laboratory experiments were conducted in four 4-litre glass digesters, placed in a temperature-controlled room of $30^{\circ} \mathrm{C}$. The digestion units were mechanically mixed every $10 \mathrm{~min}$ for $10 \mathrm{~s}$ at appr. $100 \mathrm{rev} / \mathrm{min}$. Gas production was determined by means of a brine displacement system. In addition a $6-\mathrm{m}^{3}$ insulated steel digester has been used in these experiments. The contents of the pilot plant digester were kept at a constant temperature of $30 \pm 2{ }^{\circ} \mathrm{C}$ by circulating electrically heated water $\left(35^{\circ} \mathrm{C}\right)$ through the digester bottom and an internal heat exchanger (see Fig. 1). Mixing was accomplished by intermittent mechanical stirring at the bottom of the digester $(0.7 \mathrm{rev} / \mathrm{min})$ and at the top of the digester (30 rev/min). Fresh manure was added from a manure holding tank at the bottom of the digester every $30 \mathrm{~min}$ for $1 \mathrm{~min}$ by means of an adjustable mono-pump. The fresh manure displaced an equal quantity of the digester contents via an overflow system at the upper part of the digester into an effluent storage tank.

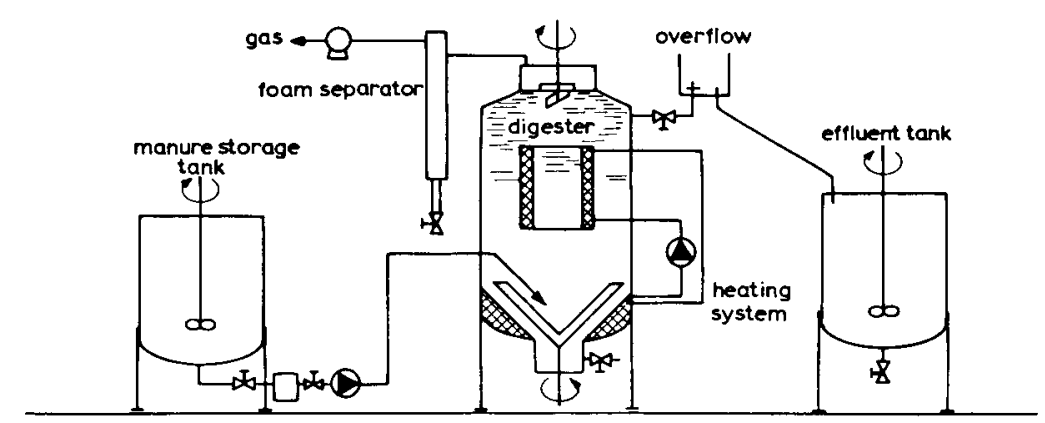

Fig. 1. Experimental pilot plant digester $\left(6 \mathrm{~m}^{3}\right)$. 
Table 1. Chemical characteristics of the seed materials.

\begin{tabular}{lcc} 
& Laboratory & Pilot plant \\
TS (g/litre) & 36.0 & 31.6 \\
VS (g/litre) & 22.2 & 21.5 \\
$\mathrm{NH}^{+} 4^{-\mathrm{N}}(\mathrm{mg} \mathrm{N} / \mathrm{litre})$ & 900 & 336 \\
total N (mg N/litre) & - & 1420 \\
COD total (mg/litre) & - & 26900 \\
COD supernatant (mg/litre) & 700 & 980 \\
COD of the VFA (mg/litre) & 0 & 18 \\
Acetic acid (meq/litre) & 0 & 0.3 \\
Propionic acid (meq/litre) & 0 & 0 \\
\hline
\end{tabular}

In view of this feeding procedure the pilot plant digester can be considered as a continuously fed system. The gas was discharged at the top of the digester whereas the gas production was measured with a dry gas meter.

Analyses

The total solids (TS) concentration was determined by drying a 10-ml sample in a $105^{\circ} \mathrm{C}$ stove overnight. Volatile solids (VS) concentration was determined by ignition of the dried samples to constant weight. Chemical oxygen demand (COD) analyses were conducted according to the Standard methods (American Public Health Association, 1965).

Ammonia-nitrogen was determined by destillation at $\mathrm{pH} 7.6$ into a boric acid solution and titration with a standard acid solution $\left(0.02 \mathrm{~N} \mathrm{H}_{2} \mathrm{SO}_{4}\right)$. The total nitrogen concentration was estimated by boiling a $10-\mathrm{ml}$ sample in concentrated $\mathrm{H}_{2} \mathrm{SO}_{4}$ and selenium mixture GR (catalysator) until the samples were clear. After neutralization with concentrated $\mathrm{NaOH}$ the ammonia-nitrogen was determined according to the method described above.

The volatile fatty acids (VFA) were determined on a gas chromatograph with a packed glass column $(1 \mathrm{~m} \times 0.4 \mathrm{~cm}$ i.d.) filled with Tween 80 on Chromosorb W-AW 80/100. Column temperature was $115^{\circ} \mathrm{C}$ and the carrier gas, $\mathrm{N}_{2}$, was saturated with formic acid.

Gas analyses were performed with an Orsatt apparatus in the laboratory experiments and by means of a portable combustible gas meter calibrated for methane in the pilot plant experiments.

\section{Materials}

The seed material for the laboratory and pilot plant experiments was obtained from the municipal sewage plants at Zeist and Ede respectively. Some chemical characteristics of both seed sludges are summarized in Table 1.

The manure used in the investigation consisted of both urine and faeces. The relevant chemical characteristics of the manure are summarized in Table 2 . The manure used in the laboratory experiments was obtained from piggeries with a slatted-floor system and did not contain any litter material. If necessary the manure 
was diluted with tap-water to a TS concentration of about $60 \mathrm{~g} /$ litre. The experiments have been conducted with two different batches of manure, which were stored at $4{ }^{\circ} \mathrm{C}$. From analyses made twice a week during the storage period it appeared that storage at $4{ }^{\circ} \mathrm{C}$ hardly affected the chemical composition of the manure.

The pig manure used in the pilot plant experiment was obtained from an experimental farm where the manure solids and the manure liquid were discharged separately. Before digestion both fractions were combined in appropriate proportions. The manure in this case partly consisted of saw dust and other litter material. As the manure concentration varied considerably, only the maximum, the minimum and the average values are given in Table 2.

\section{Experimental procedure}

In order to investigate the influence of the loading rate upon the acclimation, different loading rates have been applied in the start-up of the laboratory experiments. Since in all experiments the manure used had a TS concentration of ca. $60 \mathrm{~g} / \mathrm{litre}$, the desired organic loading rate could be obtained by adjusting the detention time.

Each digester was seeded with 4 litres of digested sewage sludge and heated to $30{ }^{\circ} \mathrm{C}$. The manure was added once a day after discharging an equal quantity of the digester contents. The experiments were continued until a stable process had been achieved at a 15-day detention time (organic load $4.0 \mathrm{~kg}$ TS $\mathrm{m}^{-3}$ day $^{-1}$ ) because this loading rate was shown in previous experiments (van Velsen, 1977) to be optimum with respect to both the gas production and the reduction of malodourous components.

The pilot plant was seeded with $6 \mathrm{~m}^{3}$ of digested sewage sludge and heated to ca. $30{ }^{\circ} \mathrm{C}$. Based on the results of the laboratory experiments fresh manure was added at a loading rate of ca. $2.5 \mathrm{~kg} \mathrm{TS} \mathrm{m}^{-3}$ day $^{-1}$ (detention time 20 days) directly from the start of the experiment. At day 67 the loading rate was increased to ca. $3.5 \mathrm{~kg} \mathrm{TS} \mathrm{m}^{-9}$ day $^{-1}$ (detention time 15 days).

Table 2. Chemical manure characteristics.

\begin{tabular}{|c|c|c|c|c|c|}
\hline & \multicolumn{2}{|l|}{ Laboratory } & \multicolumn{3}{|c|}{ Pilot plant } \\
\hline & day $0-147$ & day $147-200$ & average & maximum & minimum \\
\hline TS (g/litre) & 57.5 & 61.7 & 58.3 & 93.9 & 29.5 \\
\hline VS (g/litre) & 38.2 & 46.3 & 43.9 & 64.6 & 21.6 \\
\hline $\mathrm{pH}$ & - & - & 7.03 & 7.92 & 6.4 \\
\hline $\mathrm{NH}^{+}{ }_{4}-\mathrm{N}(\mathrm{mg} / \mathrm{litre})$ & 1675 & 2480 & 1200 & 1800 & 720 \\
\hline total N (mg/litre) & 3400 & 4230 & 2680 & 3800 & 1570 \\
\hline COD total (mg/litre) & 58500 & 60000 & 51750 & 116500 & 28000 \\
\hline COD supernatant (mg/litre) & 15900 & 23500 & 8437 & 16250 & 4100 \\
\hline COD of the VFA (mg/litre) & 8700 & 15200 & 4775 & 8700 & 1580 \\
\hline Acetic acid (meq/litre) & 65 & 100 & 40.3 & 72.7 & 13.2 \\
\hline Propionic acid (meq/litre) & 28 & 4 & 9.1 & 17.7 & 3.4 \\
\hline
\end{tabular}




\section{Results}

The course of the gas production, the VFA concentration, the ammonia-nitrogen concentration and the $\mathrm{pH}$ of the mixed liquor in all experiments are graphically shown in Fig. 2, together with the organic loads applied. From these results it appears that the course of the process was very similar in all experiments. After feeding the gas production started immediately without any appreciable accumulation of VFA in the digester mixed liquor in the first weeks after the start of the experiments. However, in the course of the experiments the VFA concentration increased in all cases, indicating that the digestion process was in unbalance. Nevertheless the feeding of the digesters was continued at the same level. In spite of this all digesters recovered within about 3 months. Some of the more characteristic features of the start-up period as observed in the laboratory experiments, such as the maximum total VFA, the maximum acetic acid and the maximum propionic acid concentration and the duration of the period of unbalance, are summarized in Table 3. For this purpose the digestion process is considered to be unbalanced at VFA concentrations in excess of $10 \mathrm{meq} /$ litre.

In comparison with the laboratory experiments, where the increase in the VFA concentration started ca. 25 days after the initial feeding, the increase in the VFA concentration in the pilot plant experiment was significantly delayed as it only took place after 110 days.

In case of unbalanced digestion the smell of the digester effluent as determined by personal observation was rather obnoxious and more or less similar to the smell of fresh manure. However, after recovery of the process the odour was significantly less objectionable.

As appears from the data in Table 4 concerning the gas production yields the digestion process has not been significantly affected by the temporarily upset of the digester. The higher gas yield as found in the pilot plant experiment relative to that in the laboratory experiments should be attributed to the presence of variable amounts of litter material in the pilot plant manure.

After recovery of the process the organic load was increased in all experiments

Table 3. Summary results of the laboratory experiments.

\begin{tabular}{|c|c|c|c|c|}
\hline & Exp. 1 & Exp. 2 & Exp. 3 & Exp. 4 \\
\hline Load at acclimation $\left(\mathrm{kg}\right.$ TS $\left.\mathrm{m}^{-3} \mathrm{day}^{-1}\right)$ & $2.0-1.5$ & 2.4 & 3.0 & 3.6 \\
\hline Sludge load $\left(\mathrm{kg} \mathrm{COD} \mathrm{kg} \mathrm{VS}^{-1}\right.$ day $\left.^{-1}\right)$ & 0.070 & 0.084 & 0.105 & 0.126 \\
\hline $\begin{array}{l}\text { Duration of acclimation period } \\
\text { (days after the initial feeding)* }\end{array}$ & 93 & 117 & 106 & 131 \\
\hline Duration period of unbalance (days)* & 48 & 71 & 80 & 84 \\
\hline Maximum VFA concentration (meq/litre) & 40 & 64 & 65 & 64 \\
\hline Maximum acetic acid conc. (meq/litre) & 38 & 50 & 42 & 55 \\
\hline Maximum propionic acid conc. (meq/litre) & 8 & 14 & 22 & 27 \\
\hline
\end{tabular}

* The digestion process is arbitrarely considered to be unbalanced at VFA concentrations in excess of $10 \mathrm{meq} / \mathrm{litre}$. 

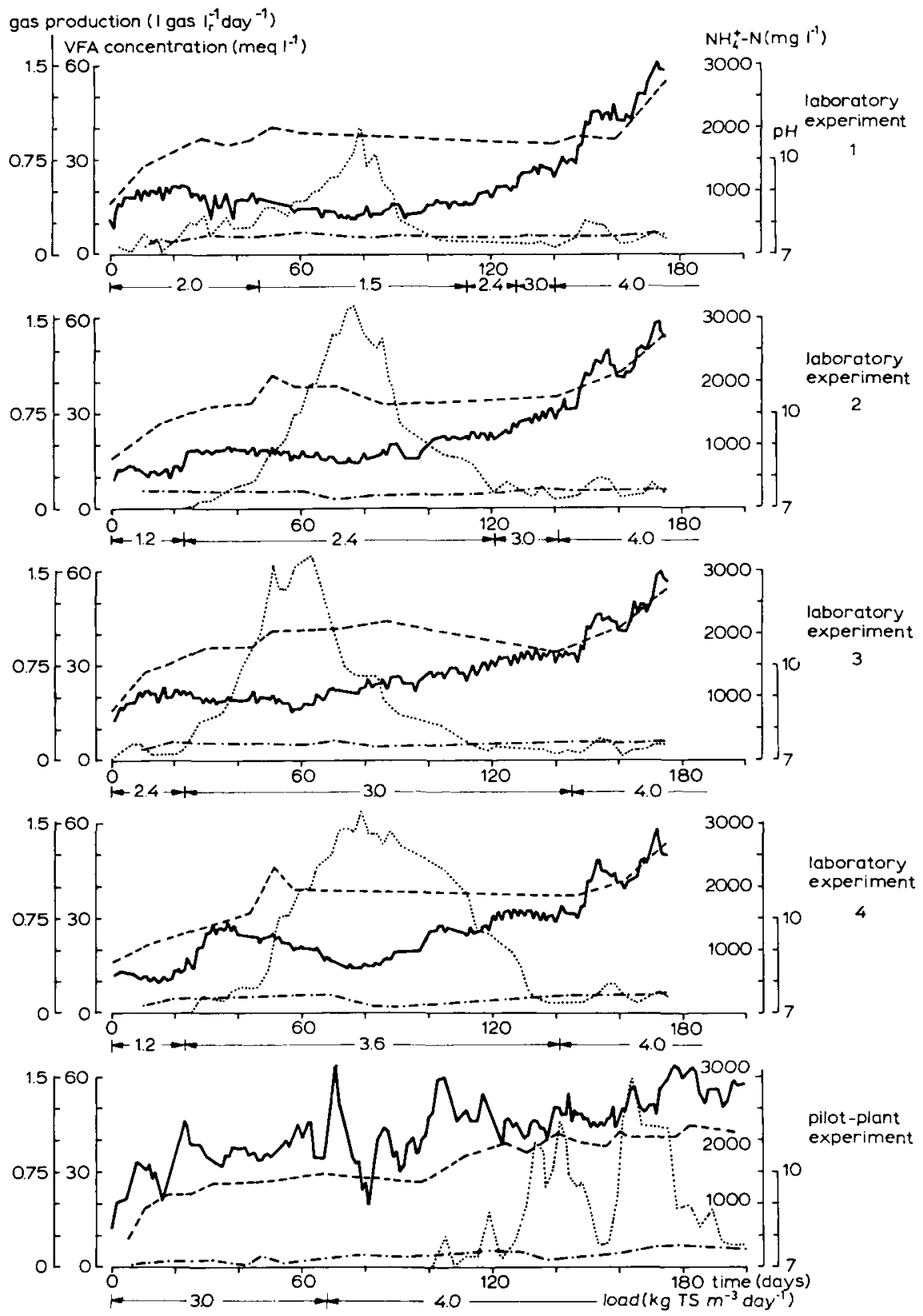

Fig. 2. Course of the digestion process in the start-up period of the laboratory and pilot plant experiments. —- gas production;....... VFA concentration; - ammonia-nitrogen concentration; .-....... $\mathrm{pH}$. 
Table 4. Methane production before and after the period of unbalanced digestion.

\begin{tabular}{|c|c|c|c|c|c|}
\hline & \multicolumn{4}{|c|}{ Laboratory } & \multirow[t]{2}{*}{ Pilot plant } \\
\hline & Exp. 1 & Exp. 2 & Exp. 3 & Exp. 4 & \\
\hline \multicolumn{6}{|l|}{ Before period of process unbalance } \\
\hline Load (kg TS $\mathrm{m}^{-3}$ day-1) & $\begin{array}{l}2.0 \\
0.173\end{array}$ & $\begin{array}{l}1.2 \\
0.207\end{array}$ & $\begin{array}{l}2.4 \\
0.181\end{array}$ & $\begin{array}{l}1.2 \\
0.195\end{array}$ & $\begin{array}{l}2.5 \\
0.227\end{array}$ \\
\hline \multicolumn{6}{|l|}{ After period of process unbalance } \\
\hline Load $\left(\mathrm{kg}\right.$ TS $\mathrm{m}^{-3}$ day $\left.{ }^{-1}\right)$ & 2.4 & 3.0 & 4.1 & 3.6 & 3.5 \\
\hline $\mathrm{CH}_{4}$ production $\left(\mathrm{m}^{3} \mathrm{CH}_{4} / \mathrm{kg}\right.$ TS added $)$ & 0.186 & 0.184 & 0.165 & 0.172 & 0.265 \\
\hline
\end{tabular}

to $4.0 \mathrm{~kg} \mathrm{TS} \mathrm{m}^{-3}$ day $^{-1}$ by decreasing the detention time gradually to 15 days (see Fig. 2). At about the same time (day 147) it was necessary to use in the laboratory experiments a manure of a slightly different chemical composition (see Table 2).

Both these changes apparently did not affect the process stability. At the end of the experimental period the digestion process proceeded very similarly in all laboratory digesters and the results were in accordance with those of previous experiments (van Velsen, 1977) at comparable process circumstances (see Table 5).

\section{Discussion}

Digested sewage sludge apparently is a very suitable material for seeding a pig manure digester since the methane formation started immediately upon feeding with pig manure under the circumstances investigated, reaching its maximum value $\left(\mathrm{m}^{3} \mathrm{CH}_{4}\right.$ per $\mathrm{kg}$ TS added) already in the first week after the start of the feeding (see Table 3). These observations indicate that the anaerobic organisms present in digested sewage sludge can metabolize the digestible constituents of the pig manure without requiring an acclimation period.

Table 5. Comparison of the average results of the present laboratory experiments at the end of the experiments (day 200) with the results of previous experiment at similar process circumstances (van Velsen, 1977). Manure concentration: $60 \mathrm{~g}$ TS; detention time 15 days; temperature $30^{\circ} \mathrm{C}$.

\begin{tabular}{lcc}
\hline & Previous results & Present results \\
$\mathrm{CH}_{4}$ production (m ${ }^{3} \mathrm{CH}_{4} / \mathrm{kg}$ TS added) & 0.197 & 0.202 \\
$\mathrm{pH}$ & 7.8 & 7.55 \\
$\mathrm{NH}{ }_{4}-\mathrm{N}$ (mg N/litre) & 2675 & 2750 \\
$\mathrm{TS}$ reduction (\%) & 30.8 & 31.6 \\
VS reduction (\%) & 39.2 & 42.6 \\
VFA concentration (meq/litre) & 3.5 & 5.0 \\
Acetic acid (meq/litre) & 3.5 & 3.1 \\
Propionic acid (meq/litre) & 0 & 1.3 \\
\hline
\end{tabular}


On the other hand all experiments were characterized by the occurrence of a period of process unbalance as indicated by the increase in the VFA concentration. In fact an increase in the VFA concentration in anaerobic processes as a rule reveals that the rate of methane formation is not sufficient to metabolize all the VFA offered. In the present experiments the increase in the VFA concentration has to be attributed to an inhibition of the methane-forming organisms, since it is always attended by a decrease of the gas production. As the sum of the COD removed via the methane gas and the VFA-COD, present in the digester mixed liquor, remained almost unchanged at various instants during the experiments, it is evident that in periods of unbalance the methane formation was inhibited.

Since the original seed material was well acclimated to pig manure, the inhibition of the methane formation apparently has to be attributed to changes in the environmental conditions of the digester contents as a result of the gradual displacement of the original mixed liquor by wet pig manure. A very significant change concerns the increase in the ammonia-nitrogen concentration of the digester contents. As in all experiments the VFA concentration only started to increase as soon as the ammonia-nitrogen concentration in the digester contents reached a level of ca. $1.7 \mathrm{~g} /$ litre, the experimental results point to ammonianitrogen as being the inhibiting compound if a concentration of ca. $1.7 \mathrm{~g} /$ litre is reached. The presumed critical concentration of $1.7 \mathrm{~g} /$ litre is reached after 110 days in the pilot plant experiment and after 3-6 weeks in the laboratory experiments (Fig. 2). The start of the period of retarded methane formation in all cases coincides with the time at which the ammonia-nitrogen threshold value of ca. $1.7 \mathrm{~g} /$ litre is reached, independent whether this lasts 3 weeks of 15 weeks.

From the literature it appears that ammonia-nitrogen at concentrations exceeding ca. $1500 \mathrm{mg} /$ litre may greatly influence the methane formation. McCarty \& McKinney (1961) and McCarty (1964) stated that ammonia-nitrogen concentrations of 1.5 to $3.0 \mathrm{~g} /$ litre are inhibitory at $\mathrm{pH}$ levels above 7.4 and that the ammonium ion itself becomes toxic regardless of $\mathrm{pH}$ at concentrations exceeding $3 \mathrm{~g} /$ litre. Literature concerning the anaerobic digestion of farm wastes reveals that at ammonia-nitrogen concentrations below the threshold level of ca. $1.5 \mathrm{~g} /$ litre no accumulation of VFA takes place (Fischer et al., 1977; Gramms et al., 1971; Miner \& Smith, 1975) whereas at ammonia-nitrogen concentrations exceeding this level the VFA concentrations increases in course of the experiment (Miner \& Smith, 1975; Lapp et al., 1975; Kroeker et al., 1976; Schmid \& Lipper, 1969; Hart, 1963). From this some workers concluded that the ammonia-nitrogen concentration exceeding $1.5 \mathrm{~g}$ /litre effected process failure (Schmid \& Lipper, 1969; Miner \& Smith, 1975) or process inhibition (Gramms et al., 1971). On the other hand various other workers reported a satisfactory digestion of animal wastes at ammonia-nitrogen concentrations exceeding $1.5 \mathrm{~g} /$ litre in long-term experiments (Lapp et al., 1975; Lapp et al., 1975; Kroeker et al., 1976; Fisher et al., 1977; Converse et al., 1977; Summers \& Bousfield, 1976; van Velsen, 1977; Hobson et al., 1976). Unfortunately in all investigations cited above the course of the ammonia-nitrogen concentration during the digestion was not 
measured. Therefore it is impossible to assess from these reports the ammonianitrogen concentration at which the VFA concentration starts to increase.

According to observations of Melbinger \& Donnellon (1971, 3.2.02) in digestion experiments with concentrated sewage sludge and our own observations (van Velsen, 1979) in digestion experiments on the fermentation of VFA, the inhibition of methane formation by ammonia-nitrogen at concentrations exceeding ca. 1.5 to $1.7 \mathrm{~g} /$ litre is only temporary, as long as the methanogenic organisms are allowed to acclimate to these ammonia-nitrogen concentrations. Consequently the process recovery in the present experiments has to be attributed to the ability of the methanogenic population to adapt to the high ammonia-nitrogen concentrations. The results of the laboratory experiments (see Table 3 ) reveal that the concentration of the VFA, especially that of propionic acid, and the duration of the period of unbalanced digestion both increase at increasing loading rates. Since only $6 \%$ TS manure was used in these experiments an increased organic loading rate inherently is attended by an accelerated increase in the ammonia-nitrogen concentration. Therefore these results do not allow us to make any conclusion about the question whether the increased loading rate or the accelerated rise in the ammonia-nitrogen concentration predominates with respect to the height of the VFA concentration and the duration of process unbalance.

With respect to the procedure to be followed in the start-up of farm-scale

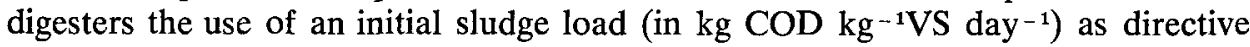
should be preferred over the space load, because frequently the quantity of seed sludge available for start-up will be insufficient to fill the digester completely. The results obtained in the present experiments indicate that a digester can be started succesfully at sludge loads up to $0.126 \mathrm{~kg} \mathrm{COD} \mathrm{kg}^{-1} \mathrm{VS}$ day-1 (see Table 3). The digester should be fed for a period of ca. 2.5 months at this loading rate in order to allow the sludge to acclimate. If necessary the loading rate can then be increased stepwise to the final level.

During the start of the digestion a fall of the $\mathrm{pH}$ below 7 is very unlikely, because as a rule sufficient ammonia-nitrogen is present to neutralize the VFA, even in case of severe accumulation of these intermediates. The results obtained indicate that methanogenic sludge, once it is acclimated to an ammonia-nitrogen concentration of ca. $1.7 \mathrm{~g} /$ litre, is also acclimated to ammonia-nitrogen concentrations up to $2.7 \mathrm{~g} /$ /itre which were reached beyond day 147 due to the use of the other batch of pig manure. This is in accordance with the results of previous experiments (van Velsen, in press) which indicated that digested pig manure having an ammonia-nitrogen concentration of $2.41 \mathrm{~g} /$ litre was also acclimated to an ammonia-nitrogen concentration of $3.075 \mathrm{~g} /$ litre in the fermentation of VFA.

Although the initial feeding rate markedly affects the acclimation process it apparently has no clear effect on the final digestion characteristics, because the performance of the 4 laboratory digesters at the end of the experiments is very similar. Moreover, the results were very similar to those of previous experiments (van Velsen, 1977). Therefore, it seems reasonable to conclude that the start-up period is especially important to provide optimum circumstances for the acclimation of the organisms to the increasing ammonia-nitrogen concentrations and that the 
loading rate does not influence the operation of the digestion process once acclimation has taken place.

\section{Conclusions}

- Anaerobic digested sewage sludge is a suitable material for seeding a pig manure digester. The process can be started up at a sludge load of $0.125 \mathrm{~kg} \mathrm{COD} \mathrm{kg}^{-1}$ VS day ${ }^{-1}$.

- The methane formation by anaerobic sewage sludge is slightly inhibited by ammonia-nitrogen when the concentration in the digester contents reaches a level of ca. $1.7 \mathrm{~g} /$ litre. This inhibition is only temporary if the bacteria are allowed to acclimate to this ammonia-nitrogen concentration.

- Once acclimated to an ammonia-nitrogen concentration of ca. $1.7 \mathrm{~g} /$ litre the methanogenic sludge is also acclimated to much higher concentrations, viz 2.75 $\mathrm{g} /$ litre at the minimum as observed in the present experiments.

- The VFA concentration in the digester contents at unbalanced digestion as well as the duration of the period of unbalancy increase at increasing loading rates applied.

\section{References}

American Public Health Association, 1965. Standard methods of water and sewage analysis, 12th ed.

Converse, J. C., G. W. Evans, C. R. Verhoeven, W. Gibbon \& M. Gibbon, 1977. Performance of a large size anaerobic digester for poultry manure. ASAE Paper No 77-0451.

Fischer, J. R., E. L. Ianotti, J. H. Porter and A. Garcia, 1977. Producing methane gas from swine manure in a pilot-size digester. ASAE Paper No MC77 - 604 (March).

Fischer, J. R., N. F. Meador, D. M. Sievers, C. D. Fulhage \& E. L. Iannotti, 1977 Design and operation of a farm-size anaerobic digester for swine. ASAE Paper No 77-4052 (June).

Gramms, L. C., L. B. Polkowski \& S. A. Witzel, 1971. Anaerobic digestion of farm animal wastes. Trans. Am. Soc. agric. Engrs 14 (1) 7-13.

Hart, S. A., 1963. Digestion tests of livestock wastes. J. Water Poll. Control Fedn 35 (6) 748-757.

Hobson, P. N. \& B. G. Shaw, 1973. The anaerobic digestion of waste from an intensive pig unit. Water Res. 7: 437-449.

Hobson, P. N. \& B. G. Shaw, 1976. Inhibition of methane production by Methanobacterium formicicum. Water Res. 10: 849-852.

Kroeker, E. J., H. M. Lapp, D. D. Schulte, J. D. Haliburton \& A. B. Sparling, 1976. Methane production from animal wastes. 11. Process stability. CSAE Paper No 76-208.

Lapp, H. M., D. D. Schulte, E. J. Kroeker, A. B. Sparling \& B. H. Topnik, 1975. Start-up of pilot scale swine manure digesters for methane production. In: Managing livestock wastes. ASEA publication PROC-275: 234-237.

Lapp, H. M., A. B. Sparling, D. D. Schulte \& L. C. Buchanan, 1975. Methane production from animal wastes. 1. Fundamental considerations. Can. agric. Engng 17: 97-101.

McCarty, P. L. \& R. E. McKinney, 1961. Salt toxicity in anaerobic digestion. J. Water Poll. Control Fedn 33: 399-415.

McCarty, P. L., 1964. Anaerobic waste treatment fundamentals. III. Public Works (Nov.) 91-94.

Melbinger, N. R. \& J. Donnellon, 1971. Toxic effects of ammonia nitrogen in high-rate digestion. J. Water Poll. Control Fedn 43 (8) 1658-1668.

Miner, J. R. \& J. R. Smith (Ed.), 1975. Livestock waste management with pollution control.

Neth. J. agric. Sci. 27 (1979) 


\section{A. F. M. VAN VELSEN}

North Central Regional Research Publication 222. Midwest Plan Service Handbook MWPS$19 ;$ pp. 83.

Schmid, L. A. \& R. I. Ripper, 1969. Characterization and anaerobic digestion. In: Animal waste management. Proc. Cornell Univ. Conf. agric. Waste Mgmt (1969).

Summers, R. \& S. Bousfield, 1976. Practical aspects of anaerobic digestion. Process Biochem. (June) 3-6.

Velsen, A. F. M. van, 1977. Anaerobic digestion of piggery waste. I. The influence of detention time and manure concentration. Neth. J. agric. Sci. 25: 151-169.

Velsen, A. F. M. van (in press). Adaption of methanogenic sludge to high ammonia-nitrogen concentrations. Water Res. 